\title{
'Foreigners are stealing our birth right': Moral panics and the discursive construction of Zimbabwean immigrants in South African media
}

\author{
Felix Banda and Aquilina Mawadza
}

\begin{abstract}
We examine 575 randomly selected articles on Zimbabwean immigrants from the South African Media (SAM) database to expose discourses of exclusion and the production of the psycho-social condition - moral panic. We use critical discourse analysis, notions of remediation and immediacy to scrutinize discourse structures and other discursive strategies designed to conceal mediation and authorial prejudices, and to make the reader 'experience' the actual content. In addition to making the anti-immigrant rhetoric appear legitimate, and the danger immediate and real, we argue that the apparent seamless content is often biased by selection and structured in such a way as to deny voice to immigrants and their advocates. Among other things, we conclude that since the readers' interpretations are filtered through lenses of subjectivities defined by communicative contexts characterized by job scarcity, poverty, crime and wanting healthcare, the news content heightens anxiety and miseducates more than it enlightens readers on migration issues. Hence there is a danger of SAM becoming unwitting conveyors of the same vices they preach against.
\end{abstract}

\section{Introduction}

In this article we use the online archive $S A M$ Database to examine the discursive construction of Zimbabwean immigrants in SAM. The SAM Database sources stories from all hardcopy and electronic newspapers in South Africa (SA). It offers access to more than three million newspaper reports and periodical articles that have been indexed on computer since 1978 (http://www.samedia.uovs.ac.za/, accessed 21 May 2012).

The SAM Database search engine allows for searches using different word combinations to extract articles from various print media within the database. This feature allowed the authors to gain a relatively broad insight into how the media presents the issue of Zimbabwean immigration to SA, and formed the context of the analysis. The search function also enabled easy identification of articles containing references to Zimbabwe, Zimbabwean, South Africa, im/migrant and im/migration, refugee, foreigner. The articles of interest included reports, editorials and op-ed pieces. These were scanned then classified in terms of dominant immigration metaphors, discourse structures, lexical choices and underlying moral panics. 
The database used in the paper spans the period 2000 to 2012. Given that Zimbabwean immigration to SA is a very broad topic, a reasonably long time frame of 12 years was selected for the present analysis to better understand the representation of Zimbabwean immigrants during an economically and politically unstable time in Zimbabwe. Five hundred and seventy-five (575) articles were randomly selected. Of this total $70 \%$ were published in five national newspapers: the Star $(n=134)$, the Mail and Guardian ( $n=$ 132), The City Press $(n=37)$, the Sowetan $(n=71)$ and The Sunday Times $(n=32)$. From the 575 articles, 36 are used to illustrate and support the various arguments made in this article. In line with the psycho-social nature of moral panics and in keeping with the critical discourse analysis (CDA) tradition of exposing power abuse and opaque discriminatory material in otherwise innocent-looking discursive practices, data collection focused on those headlines and stories written in such a manner as to demand that someone be blamed for imagined or real problems South African society suffers as a consequence of immigration. This is to account for the notion of moral panic which, according to Cohen (2002) and Goode and Ben-Yehuda (1994), refers to the emergence of an imagined threat to society, fuelled by media, that demands an immediate response. They note that it is typical of moral panics that the threat is exaggerated, and that someone is blamed for it.

The aim of the article is to examine the media headlines and stories to expose the discourses of exclusion and the social production of the psycho-social condition - moral panics. We want to note that given SA's history of apartheid, one would not expect these respectable newspapers to intentionally construct exclusionist or xenophobic stories. We also want to note that SAM does sometimes write positive news on immigrants, especially in how they have rejuvenated the entrepreneurial spirit in South African townships. It is often that this same success ignites xenophobic attacks on immigrants who are attacked for 'killing' local businesses with 'cheap' goods and services (Peberdy and Rogerson, 2000). Second, immigrants are often linked to crime (Crush and Williams, 2004; Danso and McDonald, 2001) and are usually described in what Crush and Williams (2004: 2) call 'highly generalized language which fails to recognize the complexity of the migration phenomenon and the manifold distinctions between different kinds of migrants and immigrants'. However, our interest is in on how newspaper articles can indirectly and unintentionally perpetrate prejudiced discourses through their selection of content, news sources and who to quote, as well as discourse structures, lexicon, argument organization and so on.

\section{The nature of Zimbabwean migration to South Africa}

Zimbabwe is landlocked, sharing a 200-kilometre southern border with SA, and is bounded on the southwest and west by Botswana, in the north by Zambia, and in the northeast and east by Mozambique. Zimbabwe achieved internationally recognized independence in April 1980, following a long period of colonial rule and a 15-year period of 'self-rule' after whites refused to have all-race elections even after the British colonial government had relinquished power.

Historically, Zimbabwe has been a country of net immigration (Zinyama and Tevera, 2002). However, since 1980, the year of Zimbabwe's independence, migration patterns have shown a net loss in the population with emigration occurring in three main waves. 
First was the emigration of white Zimbabweans after independence, the second followed the massacres in Matabeleland in the 1980s, and the most recent wave occurred among black Zimbabweans for political and economic reasons. Zimbabweans who emigrate to SA either to settle there or use it as transit route to other places in the world. A significant portion of the Zimbabwean immigration to SA is clandestine (Landau, 2008), making both their detection and the provision of accurate statistics by the authorities difficult.

The subject of how many Zimbabweans live in South Africa has been and remains controversial. Crush (2011: 5) states that over the last decade, Zimbabwe has become a major country of origin of migrants to South Africa. In July 2014, the Statistician General in South Africa indicated that Zimbabwe contributes the greatest number of immigrants, accounting for the 'lion's share'.1 This statement was said with reference to documented migrants. Crush (2011) notes that accurate information on migrant numbers remains difficult to obtain largely because of irregular migration patterns.

Moreover, the number of undocumented migrants who enter neighbouring countries through official ports and then over-stay, and those who travel without valid travel documents, are often unaccounted for (Zinyama and Tevera, 2002). Landau (2008) adds that the boundaries between African nations are rooted in the legacy of colonialism, and have little bearing on delineations between languages, cultures and 'tribes'. Thus, due to physiological and linguistic similarities with local populations, many Zimbabwean immigrants are effectively able to 'disappear', their 'foreign' status largely invisible to observers once in neighbouring countries.

\section{Topoi, moral panics and semiotic remediation}

This article assumes there is a relationship between discourses of exclusion emanating from xenophobic, anti-Semitic, homophobic and sexist behaviour, and the psycho-social condition of moral panic. One would expect there should be a decrease in exclusionist tendencies through globalization and attendant diversity as championed in the rhetoric of world leaders, the media and significant others. However, as Wodak (2000a) notes as globalization tendencies increase and borders become blurred, contradictory nationalistic movements become of the essence as the fight for space and resources intensifies and takes on a completely new dimension. There is need to unravel the contradictions in which globalization entails re-orientation to a more egalitarian world and yet the maintenance of the unequal status quo in the world order remains. The idea of global citizenship becomes moot as nationalistic tendencies and 'global clubs' such as the European Union take measures to strengthen their borders and immigration policies to keep out those are not European enough, or who come from 'outside' the union. This gives credence to Makoni's (2012: 192-193) argument that the idea of (super)diversity becomes 'a social romanticism . . . celebrated by the powerful', while the less powerful in society and those from the less powerful 'parts of the world feel the idea . . . is a careful concealment of power differences', thus 'creating an illusion of equality in a highly asymmetrical world'.

We agree with Wodak (2000b), who argues that the new rhetoric of globalization conceals many unresolved issues, and that due to the many opposing and contradictory discourses, the achievements of rapid social changes in postmodernity are accompanied by a step

\section{http://repository.uwc.ac.za}


'backward' and new scapegoats. Immigrants are new scapegoats for the socio-economic ills and other instabilities in the nations.

There is thus a need to re-evaluate the rhetoric of globalization and nationhood. In this respect, the role of CDA to 'expose the strategies and methods of such populist rhetoric and thereby to make it vulnerable to attack and counteract' (Wodak, 2000a: 1) cannot be overemphasized. Following Van Dijk (2001: 96), we apply CDA in the knowledge that it 'focuses on social problems, and especially on the role of discourse in the production and reproduction of power abuse or domination'. Wodak (2000a) has shown that commonsense argument structures or topoi are used in exclusionist discourses to give an illusion of fact and reality. In her comparison of six European countries' Parliamentary debates by politicians on autochthonous and immigrant cultural, ethnic and religious minorities in Austria, France, Great Britain, Italy, Spain and the Netherlands, Wodak (2000a) found that the commonest topoi related to:

1. Immigrants abuse the system. For example, they live at the expense of the taxpayers.

2. Immigrants are a threat to society. They tend to be criminals.

3. A liberal immigration policy promotes illegal immigration.

4. Immigrants endanger the jobs of the 'indigenous' population or take jobs from them.

5 . Immigrants cost too much (topos of numbers).

In this article we link topoi to the psycho-social notion - moral panic - to gain insight into the ideological construction of 'othering' of Zimbabwean immigrants. Moral panic is a condition that arises when a person is defined as a threat to societal values and interests (Welch et al., 2002). Husbands (1994) argues that moral panic is a creation of the media, particularly relating to fears of numbers and cultural dilution or threats posed by different types of foreigners. Cohen (2002: 9) surmises that moral panics can be said to have gripped a population when:

a condition, episode, person or group of persons emerges to become defined as a threat to societal values and interests; its nature is presented in a stylized and stereotypical fashion by the mass media; moral barricades are manned by editors, bishops, politicians and other right thinking people; socially accredited experts pronounce their diagnosis and solutions ...

It is enlightening that editors, the clergy, politicians, social experts and influential people are said to be custodians of moral boundaries. Ironically, these are the people who are cited to support exclusionist discourse and they are also usually the first people quoted as condemning episodes of xenophobia and other social upheavals resulting from such discourses.

It is expected that studying moral panics would show that official policies and social responses to perceived deviance do not generally spring forth from rational debate founded on objective appraisals of the problem. The official policies and social responses are part of the material communicative contexts that shape the different moral panics, and yet these are not evaluated for inherent contradictions. The idea then is to show how 
topoi are shaped by ongoing material communicative contexts, which in turn shape the ideologies that underlie peoples' responses to the rhetorical argument structures.

Given the psycho-social nature of moral panics, we assume communicative contexts to be socio-pyschologically determined through the dynamic and ongoing interaction between a person or community and the material communicative contexts which in turn shape the ideology on which text is (re)produced (see Van Dijk, 2008). In this article, the material communicative contexts include past, prevailing and perceived future conditions of poverty, lack of healthcare and facilities, scarcity of housing, crime, diminishing job opportunities and so on. These provide the material that shapes the ongoing exclusionist discourses, which feed back into changing communicative contexts.

Since topoi and moral panics are reproduced in social contexts, we make use of the notion remediation to account for the repurposing of content as reshaped by different contexts of communication (Bolter and Grusin, 1999). A related concept of immediacy as used by Bolter and Grusin (1999) becomes important to account for erasure of the medium in the process in which media technologies foreground the content in their attempt to make the reader have 'real' experience, and also to be objective in the reporting. However, xenophobic and other discourses of exclusion can hardly be said to be objective. Additionally, the readers will interpret the content subjectively as defined by in psychosocial communicative situations. We argue that in making the reported medium appear as seamless content and reality, the media inadvertently enable transmitters of subjective prejudiced discourses to speak directly to readers and for the content to be relayed unchallenged.

We shall link the notion of immediacy with the discourse structure of quotation in particular, as described in the next section. Suffice to say that in addition to evoking legitimacy and immediacy, quotation is also about unravelling the discourse structures and strategies through which selection biases, regarding whose voice is allowed space for expression, are embedded and expressed.

\section{Discourse structure}

We need to examine how prejudiced discourses and moral panics are produced at the discourse level, that is, during the news writing and reporting. In this regard, the article is informed by socio-cognitive discourse analysis (especially Igartua and Cheng, 2009; Van Dijk, 1984, 1989, 1991, 2008) as a way to account for relationships between moral panics and related situational factors, and linguistic and other formal structures in which they are expressed. It will be argued that the media become complicit through their association and adoption of 'specific discourse genres, communicative events, topics, styles, and rhetorics' in their news reports (Van Dijk, 1989: 29). There is growing literature on the sociocognitive and ideological basis of discourse structures and how these tend to be prejudicial and construct immigrants in a negative light (see Igartua and Cheng 2009; Li, 2001; Van Dijk, 1984, 1989, 1991, 2008). Van Dijk (1991: 40) shows how the media (re)produce xenophobic and racialized discourse through deliberate choices and structuring of 'newsbeats' as well as being the architects of what should be considered as newsworthy events.

\section{http://repository.uwc.ac.za}


In his analysis of anti-racist and anti-xenophobic (xeno-racist) stances in Spanish media, Del-Teso-Craviotto (2009: 40) argues that news reports conceal 'subtle and nuanced forms of discrimination against immigrants', first through topic selection, the majority of which associate immigrants with poverty, crime and anti-social behaviour. Second, there is a tendency not to include immigrants' own voices in the discourses, while positive reports on immigrants tend to adopt a paternalistic or patronizing tone. Third, the xenoracist opinions gain prominence and credibility due to the absence of counter-arguments to balance the opposing sides of the immigration debate in the news reports (Del-TesoCraviotto, 2009).

Igartua and Cheng (2009) show in their study of the sociocognitive effects of news frames on immigration in Spain that the frame on crime growth was significantly correlated to negative cognitive responses to immigration and to heightened sentiments depicting immigration as a problem to Spain as a nation. In his presentation on racism and the European Press, Van Dijk (2006) notes that journalism is the only profession never criticized in the press and thus escapes critical public scrutiny. Further, Van Dijk (2006) summarizes the problem of racist discourses in European media as resulting from discrimination against qualified journalists of ethnic minority groups who are often denied professional access to the press, particularly in critical editorial positions; lack of diversity in daily routines of locating, collecting and quotation of relevant news sources; lack of multicultural professional education and apprenticeships for journalists; and biased production techniques centered on Eurocentric predispositions that 'emphasize our good things, and their bad things' and 'de-emphasize our bad things, and their good things'.

In his analysis of racialized media discourses in Canada, Li (2001: 28) contends that the media contribute to the social structuring of minority groups by camouflaging prejudiced discourses 'as neutral language of public discourse'. We show how SAM deliberately or unwittingly, through the '[s]tructures of headlines, leads, thematic organization, the presence of explanatory background information, style, and especially the overall selection of newsworthy topics' (Van Dijk, 1991: 41), produce, recirculate and naturalize prejudiced discourses, which in turn trigger moral panics.

\section{Topos of immigrant as a 'folk devil'}

Murray (2003) argues that the unwanted newcomer is regarded not only as a tramontane intruder who disrupts the status quo, but also as one who figuratively pollutes, contaminates, and despoils the existing moral order. Thus, it is not enough to describe immigrants as foreigners; the discourse is structured such that immigrants are negatively constructed as terrorists, armed, gangsters and conmen as shown in (1) below.

(1) Many of us live in fear of foreign gangsters and conmen. Much terror has been caused by gangs of armed Zimbabweans, Mozambicans and others. (The Sunday Times, 28 May 2008)

The general strategy of positive self-presentation and negative other presentation in discourse about Zimbabwean immigrants is done through excessive use of the possessive pronouns us and our as in the following extracts.

\section{http://repository.uwc.ac.za}


(2) THE government must tell us what it intends to do with the continued influx of illegal foreigners, especially from Zimbabwe. They come here to compete with our people for jobs, the over-stretched state healthcare system and probably social grants. (The Sunday Times, 8 June 2009)

(3) Our country is forever going to be attractive to people from neighbouring states, and to those from further afield. (The Sunday Times, 6 October 2006)

(4) We first need to look after our own people. (The Star, 29 May 2008)

(5) They come here to compete with our people for jobs. (The Sunday Times, 8 June 2009)

(6) They're taking over our country. (The City Press, 31 May 2011)

(7) Illegal aliens cost us dearly. (The Sunday Times, 1 September 2009)

(8) Foreigners stripping us of our livelihood. (The City Press, 22 May 2011)

We see that through choices in lexicon, South Africa is conveniently reconstructed as our country (3) and South Africans as our own people (4), and our people (2, 5). The possessives depict the other as outsiders who endanger the national social order. The excessive use of the in-group designator, the possessive pronoun 'our' $(5,6,8)$ and an outgroup designator, 'they' $(2,5,6)$ establishes a contrast between $u$ s and them. A look at how the media has handled 'topicalization', which Van Dijk (1991) describes as actors and actions that are put in the initial position in a sentence, is revealing. In examples 5-8, immigrants are positioned as active agents of negative actions (see Van Dijk, 1991). We are mindful that 'positioning', according to Davies and Harré (1990: 48), refers to 'the discursive process whereby selves are located in conversations as observably and subjectively coherent participants in jointly produced story lines'. However, in this case SAM have not given the immigrants the voice to engage in the debate on immigration, and thus their role is discursively and structurally fixed by others leaving them no room to formulate their own alternative multiple reflexive selves. Moreover, the absence of dialogue in the conversation means there is no 'counterweight in the balancing act of showing both sides of the immigration debate', which in turn makes prejudiced discourses appear to be sincere and reliable (Del-Teso-Craviotto, 2009: 575). Thus, Zimbabwean immigrants are identified as the source of concern and fear for South Africa's well-being. In this regard, we want to argue that Zimbabwean immigrants are constructed as the 'folk devil'. As Goode and Ben-Yehuda (1994) explain, the 'folk devil' is deviant: someone engaged in wrongdoing and whose actions are considered harmful to society. They are deemed selfish and evil, thus substantial steps must be taken to 'neutralize' their actions to allow a return to 'normality' (Goode and Ben-Yehuda, 1994: 29). The phrases cost, compete, The discourse structure to support the topos of influx of immigrants is constructed around process verbs overwhelmed, flock, pour, smothering (10-13). The choice of these verbs is meant to be indicative of a problem engulfing and threatening to the local population. 
Furthermore, the immigrants are entering SA daily (14), thereby signalling a continuous process. Zimbabwean immigration to SA is also characterized as an exodus $(10,11)$, signalling mass migrations of biblical proportions. The term 'exodus', derived from the Bible, likens Zimbabwean immigration to the exit of the Israelites when Moses and his people were escaping from Pharaoh, and exiting Egypt. This use of intertextuality ignites the schema that already exists in people's minds through prior media reports, that Zimbabwean immigrants are entering SA in droves. The greater the number, the greater the pressure they put on the local people to blame the 'other'.

\section{Topoi about economic threat}

There are several topoi rooted in economic arguments, some of which are analysed below.

\section{Moral panic over jobs.}

The moral panic pertaining to jobs is abundantly clear in the data.Some media houses maintain tensions between local job-seekers and immigrants by suggesting that the declining pool of work in SA is due to immigrants. Anxiety over job competition among SA locals is reinforced by media reports that some Zimbabwean immigrants accept jobs for lower wages.

(15) Stop flood of illegal immigrants. THE government must tell us what it intends to do with the continued influx of illegal foreigners, especially from Zimbabwe. They come here to compete with our people for jobs, the over-stretched state healthcare system and probably social grants. (The Sunday Times, 8 June 2009)

(16) Foreigners take less pay, get jobs. (The Star, 22 May 2008)

(17) Most South Africans remain unemployed despite a strong growing economy. Sectors such as the construction and hospitality industries have been growing for years. Most employers in these sectors pay exploitative salaries because they have realized there is a desperate labour force - especially from Zimbabwe that will accept any salary. This practice is undermining the government efforts to improve the lives of the poor. (The Star, 22 May 2008)

In (15) and (17), we see the metaphorical discourse about flood of illegal immigrants, especially from Zimbabwe who come here to compete with our people for jobs and therefore the government must intervene before SA collapses under the sheer enormity of numbers. We find that the government is implored to intervene on behalf of the powerless South Africans who cannot successfully compete against foreigners for jobs. Second, immigrants are accused of unfairly competing for health services and social grants they do not deserve. The discursive strategy is to depict South Africans as helpless victims and Zimbabwean immigrants as powerful aggressors. The use of the adverb especially in especially from Zimbabwe emphasizes that the problems are caused mainly by Zimbabweans. In addition, an incorrect perspective is constructed that the private sector and SA government are creating enough jobs through a growing economy, most of which are taken up by foreigners (17). A study conducted by Murray (2003: 449) shows that the 'infestation of illegal aliens' is erroneously blamed for depressing wages, consuming social services and exacerbating unemployment. 'Illegal aliens' are also blamed for social 
processes such as rising unemployment and crime - that were unrelated to, but are constructed as having begun at the same time as, the growing influx of foreign immigrants.

It is interesting that the figures and sources quoted all paint a negative picture of immigrants. The immigrants are not quoted, not even in reported speech form, to get their side of the story. In fact, the headlines and stories themselves are structured in such a way as to not give counterarguments or responses, as the reporters themselves do not evaluate the sources or the veracity of the information. It could be argued that by directly quoting sources the reporters are trying to distance themselves from the stories. It could also be argued that journalistic ethics demand that they report the news as it is without imposing their own ideology or beliefs. The use of quotation marks and other direct speech forms enables authors to strategically absolve themselves from the speech acts and the conversational implicature of the content or the message in the news. However, as argued elsewhere, this results in prejudiced discourses being peddled uncontested and hence to be prominently featured as the unquestioned truth. It appears, then, that the news media surveyed do not appear to challenge the generalizations and stereotypes in the cited stories. We want to argue that even though they may contend that they do not necessarily endorse the prejudiced discourses, the authors may be held accountable for purveying unbalanced news stories in the immigration debate.

\section{Moral panic over strain on public institutions.}

Some of the most recurrent discourse types relate to threats to individual economic security repeatedly expressed by negative references to the pressure on social services by immigrants. Thus, moral panic is created by the topos of repeated references to immigrants as a drain on the South African fiscus.

Here, the media makes direct reference to the costs associated with Zimbabwean immigrants. The perception is created that Zimbabwean immigrants have placed a strain on jobs, healthcare and housing, and that they disproportionately and unfairly benefit from the social grants. They have not been budgeted for (18), and they put pressure on public institutions meant for local South Africans.

(18) The latest figures come as South African health services struggle to cope with thousands of foreign patients who have not been budgeted for. (The Sunday Times, 23 July 2006)

Although no statistics are cited, the phrase latest figures authenticates and foregrounds the immediacy and urgency of the 'problem' of Zimbabwean immigrants unfairly benefitting from jobs, educational opportunities and social services. Moreover, we see later that immigrants are also blamed for incapacitating municipalities from discharging their basic civic duties (23).

\section{Moral panic over healthcare.}

Crush and Tawodzera (2014) suggest that one of the commonest xenophobic stereotype perspectives in SA is that immigrants are swamping hospitals and clinics, negatively impacting on South Africans' rights as citizens to access health services. As can be seen in 
(2) earlier and (19) next, the presence of Zimbabwean immigrants is seen as a constant threat to the public health system.

(19) Hundreds of Zimbabweans have sought treatment in South Africa as the death toll from the cholera outbreak rises. (The Mail and Guardian, 25 November 2008)

Furthermore, the health sector is said to be struggling to cope with hundreds of Zimbabweans [who] have sought treatment in South Africa ... [for] cholera. Crush and Tawodzera (2014) note that the South African healthcare system is heavily overburdened and is in an advanced state of disrepair in large parts of the country. The burden of healthcare is further worsened by the brain drain and the impact of the HIV/AIDS pandemic in SA. However, in (19) the juxtaposition of hundreds of Zimbabweans and the phrase as the death toll from the cholera outbreak rises makes Zimbabwean immigrants agents in the rise in death toll and cholera outbreak in South Africa. In essence, the deteriorating healthcare infrastructure, lack of medical personnel and the resulting deaths are blamed on immigrants.

\section{Moral panic over housing.}

The moral panic on housing is demonstrated through the language of 'haves' - the Zimbabwean immigrants, and 'have nots' - the SA locals. In (20-23), Zimbabwean immigrants are accused of acquiring Rural Development Programme (RDP) houses ahead of deserving legitimate and poor South Africans.

(20) You have got a house, I haven't, Get out or die! Japhet Moyo and Albert Moyo . . . . said the doors to their house had been forced open at 9pm on Sunday by a mob. They had been told to get out or be killed. Both fled to the police station. 'They asked whether I was Zimbabwean and they told me to go back to Zimbabwe but they also told me I must go because they wanted my house. They asked why I had a house but they didn't. (The Star, 18 May 2008)

(21) Foreigners are stealing our birth right: Lebogang explores allegations that Zimbabwean immigrants have taken over RDP houses in the border town of Musina. (The Star, 6 February 2006)

(22) Their influx into the area is impacting negatively on the municipality's capacity to provide basic services as we are overstretched. (The Star, 6 February 2006)

(23) 'Our brothers don't have houses and we don't know how foreigners got them.' Residents of Alexandra's RDP houses have reacted to menacing calls for foreigners to vacate RDP houses in the township within seven days with a mixture of fear and nonchalance. Last weekend groups of residents, some coordinating their movements by phone, moved around extensions seven, nine and 10 handing out flyers and putting up posters warning foreigners living in RDP houses to vacate within seven days or risk 'being pushed like animals or aliens.' (The Mail and Guardian, 21 October 2011) 
The feeling of fear is understandable, as some South Africans are married to immigrants or have leased their homes to them. In addition, some are aware that some victims of xenophobic attacks in the past included South Africans mistaken for foreigners. Discourses of exclusion are relayed in linguistic structures such as Their influx into the area is impacting negatively on the municipality's capacity to provide basic services as we are overstretched (22), where the Zimbabwean presence adversely impacts local service delivery and, therefore, South Africans may have to use force and push out the Zimbabwean immigrants like animals or aliens (23). The reference to stealing our birth right (21) displays a fear of invasion and moral panics triggered by strong emotions of nationhood and belonging. The Zimbabwean immigrant population is, therefore, a threat, as they 'do not belong' and are not part of this South African heritage.

We also see the strategy of authentication in which SA media quotes verbatim as a way to not only capture ordinary South Africans' personalized protests against immigrants, but also, we argue, to attempt to elide mediation as the person who utters the words speaks 'directly' to the readers. In this regard, 'You have got a house, I haven't, Get out or die!,' 'Foreigners are stealing our birth right' and 'Our brothers don't have houses' are indicative of the newspapers giving xenophobic persons the voice to speak directly to other frustrated South Africans. The use of quotation marks is evidence that the writer wants the readers to take the content as oral/spoken words, that is, spoken words from a source. This creates a situation of personal involvement and intimacy between the content/person quoted and the reader. It is clear that examples (20) and (21) were initially designed to gauge the immigrants' take on the issues, but the evaluation of the events by both the immigrants and the reporter are missing. Most important, the structural information that should explain why some immigrants have houses is missing, leaving only the perspective that they got them illegally. Second, the schematic ordering of the information is such that it gives prominence (such as in headings in (21) and (23)) and foregrounds the negative acts by foreigners, and hence provides justification for the attacks on immigrants $(20,21,23,25)$. The discourse constructs South Africans as a frustrated people who have been on housing lists for long periods and are still waiting for houses, whilst Zimbabwean immigrants get awarded RDP houses without a fuss:

(24) South Africans have alleged that foreigners, particularly Zimbabweans have been awarded low cost housing in preference to locals who have been on waiting lists for years. (The Star, 18 May 2008)

Remarkably, it is particularly Zimbabweans who are benefitting from RDP housing in preference to locals who have been on waiting lists for years. It is the Zimbabwean immigrants who constitute a threat. This panic is further fuelled by Zimbabwean immigrants who are reported as getting access to houses through corrupt means. In this regard, the SA border town of Musina is said to be completely taken over by Zimbabweans (25).

(25) Musina, on the border town of South Africa and Zimbabwe has supposedly been taken over by illegal immigrants, some of whom obtained South African identity documents fraudulently. Some of the Zimbabweans have taken over RDP 
houses meant for poor South Africans while others cross the border illegally to claim child grants for their children. (The Star, 6 February 2006)

The discursive construction [s]ome of the Zimbabweans have taken over RDP houses meant for poor South Africans while others cross the border illegally to claim child grants for their children shows the powerlessness of government and South Africans generally to do anything about it. The underlying meaning is that some immigrants have blended with the local population, while others employ 'guerrilla' tactics of crossing into South Africa to illegally claim child grants only to disappear into Zimbabwe, and reappear when payment to beneficiaries is due. The image constructed is that of the all powerful Zimbabwean immigrants unjustly acquiring these homes and social grants ahead of 'poor' South Africans.

\section{Moral panic over strain on state coffers.}

Through the topos of strain on state coffers, Zimbabwean immigrants are described as having looted, bled, robbed and siphoned off billions from the SA government.

(26) Foreigners are looting SA coffers. (The Sowetan, 21 July 2010)

(27) FOREIGNERS have siphoned off more than R1billion from government coffers using fraudulent identity documents to claim social grants. (The Sowetan, 21 July 2010)

(28) KwaZulu-Natal MEC for social development Meshack Radebe revealed yesterday that the government had been robbed of millions of rands by foreigners posing as poor South Africans who applied for social grants. (The Sowetan, 21 July 2010)

(29) Radebe said people from Zimbabwe, Mozambique, Lesotho and Swaziland were collecting grants fraudulently every month. He said his department was concerned that the number of foreigners collecting social grants was increasing. (The Sowetan, 21 July 2010)

(30) The department of home affairs has taken a financial knock from the influx of illegal immigrants. (News24, 23 July 2006)

Discourses designed for moral panics are expressed in such constructions as 'government has been robbed of millions of rands by foreigners', 'Foreigners are looting SA coffers' and 'financial knock'. The suggestion of looting is reminiscent of plundering, pillaging, ransacking and stealing. The discourse structure is indicative of criminal activity, particularly using fraudulent identity documents to claim social grants $(28,29)$. According to Murray (2003), such discourses serve as a convenient metaphor that exacerbates fears of cunning tricksters or scheming swindlers, who take advantage of opportunities to take resources that are denied ordinary South Africans. 


\section{Topos of crime threat}

Research on immigrants has shown that they are commonly stereotyped as likely to become involved with crime (Del-Teso-Craviotto, 2009; Dingeman and Rumbaut, 2010). Stereotypes in SA include 'foreigners are crooks' and being involved in 'sophisticated crime' as captured in (32-37). In (34) and (36), the media is confident that most heinous crime in SA is committed by Zimbabweans. Even in the absence of statistical evidence, such media discourses cause panic as so-called experts in criminology are interviewed and their quoted comments are repurposed (Bolter and Grusin, 1999) as 'evidence' or 'facts' to prove that most immigrants are essentially criminals. The following are examples that suggest a direct relationship between African, Zimbabwean migration in particular and crime:

(31) 'I have dealt extensively with foreigners, and the first thing that is said about our country is how it can allow so many undocumented foreigners to roam our country and get into all sorts of criminal activities. It really portrays our country as weak, lawless, corrupt and accommodating to all sorts.' (City Press, 29 May 2011)

(32) 'Foreign crooks very active in SA.' THE number of foreigners involved in sophisticated crime syndicates is on the rise. This was revealed by KwaZulu-Natal provincial deputy police commissioner Major-General Johan Booysen yesterday. (The Sowetan, 5 October 2010)

(33) He said there was an increase of foreigners being arrested for violent crime, drug trafficking, human trafficking and robberies. (The Sowetan, 5 October 2010)

(34) 'Most of the foreigners involved in these crimes are Zimbabweans and from West Africa, including Nigeria and Ghana,' he said. (The Sowetan, 5 October 2010)

(36) Booysen explained that highly trained foreigners arrive in South Africa in search of greener pastures and better living conditions. But because there are no job opportunities crime becomes the next option. (The Sowetan, 5 October 2010)

(36) Bongani Moyo (also known as Mojo), one of South Africa's most wanted criminals, was arrested near the Beitbridge border post in Limpopo when he returned for medical treatment, police said on Friday. Colonel Neville Malila said it was believed Moyo, 29, had fled to his native country, Zimbabwe, for three days but had tried to return to South Africa for 'urgent medical attention'. (The Sowetan, 13 May 2011)

Although statistics are not given, immigrants are criminalized via fraudulent IDs, accessing services illegally, trafficking and robberies. It is interesting that some immigrants are described as highly trained. They could have been doctors, professors, social scientists, and so on, but if they cannot get employment after crossing the border they become criminals and parasites preying on innocent South Africans. In essence, these highly trained professionals (35) are described as no different from hardened criminals such as Bongani Moyo (36). These claims about Zimbabwean immigrants being 
criminals contribute to trigger moral panics in SA and to reinforcing the distinction between us and them, leading to another topos: the topos of preserving national identity.

\section{Topos of preserving nation identity}

The concept of nation as an imagined community is critical in the analysis of SAM representation of Zimbabwean immigrants. Murray (2003) states that in SA after apartheid, the new discourses on nationalism, nation-building and national identity have fundamentally reshaped the way that ordinary South Africans see themselves as belonging to an imagined non-racial multi-ethnic community. The dominant discourses are that South Africans should unite as one nation regardless of ethnic or racial background. If the media extracts discussed earlier are anything to go by, this newfound unity of purpose and nationhood is threatened by the onslaught of immigrants. Throughout the article we have argued that the media project the picture that Zimbabwean immigrants threaten the nation and 'our nation', thereby triggering fear that the increase in numbers of immigrants will result in their taking over our country and stealing our birth right, which produces moral panics. Expressed in the caricatured format of us and them, stereotypes and common-sense argument structures assert the birth right of South African citizens while denying entitlements to 'outsiders' who 'do not belong'.

\section{Summary and conclusion}

We have shown that the selection of alarmist headlines, sensational news content, the angle and organization of argumentation structure point to a particular bias by the reporters which mutes immigrants' voices from the immigration debate. We have also shown that quotation is particularly used to evoke legitimacy and immediacy. It is also indicative of headline, content and actor bias as immigrants and other counter voices in the debate are given no platform for expression. Significantly, it gives an indication of roles and power structure in which immigrants found themselves voiceless at the lower ranks of society.

We are mindful that in general SAM were quick in their condemnation of the xenophobic attacks that took place in SA townships in May 2008 in which a number of foreigners and South Africans mistaken for foreigners were killed. At the same time, it is clear that sections of SAM are unwitting participants in the discursive construction of Zimbabwean immigrants as a threat. The apparent contradiction is palpable. Public reactions to mediafuelled moral panics about immigrant threats legitimize political leaders' resolve and the media themselves to push for harsher laws and legislation or policies under the banner of community safety, social well-being or national security. The immigrants are positioned as aggressors and their opinions on the various topics and events are ignored.

This article has also shown that common-sense arguments are semioticized as facts and materiality on which descriptions of Zimbabwean immigrants are based and consumed. We saw remediation of written content through the phrasing of the written discourse to appear conversational in order to evoke immediacy. The use of personal pronouns and direct speech reduced social distance between content (person quoted) and reader and at the same time concealed the written authorship and hence author biases. The written 
form is made to appear as 'spoken' and personalized one-on-one conversation or, at the very least, as very intimate interaction between the content/person quoted and SA reader.

It is this apparent attempt at seamless content that removes or reduces traces of mediation leading to immediacy designed to make the readers have 'real' experience by experiencing 'an immediate relationship to the contents of the medium' (Bolter and Grusin, 1999: 318) rather than with the medium itself. This heightens the tension, since the SA reader is made to be involved more intimately with the content and hence to experience the threat as immediate and real to their personal self and their nation. Since immigrants and those driving the cause of immigrants in the debate are not selected for quotation, the discursive construction of Zimbabwean immigrants as a social and economic nuisance is not challenged.

We saw the communicative contexts in which South Africans live, such as high crime rates, poverty, poor service delivery and lack of job opportunities, reframed through certain discourse types and lexical choices linked directly or indirectly to immigrants. It is these contexts that characterize the topoi which produce moral panics, which in turn reshape topoi and the readers' experiences of the communicative contexts. The relationship between discourse structures, lexical choices, topoi, moral panics, and social contexts becomes self-saving, thereby blurring boundaries between fact, fiction and common -sense arguments.

Lastly, it can be argued that the newspapers were merely reporting what others had said. But this does not absolve them of peddling unverified information from unnamed sources, and giving figures without statistical proof, as reality and fact. At the very least, they could be critical about what is being put forward for public consumption. It might also be argued that the headlines and some of the content are merely designed to capture the audience's interest. However, we would counteract that this strategy does more damage as it primes the reader to have a negative disposition towards Zimbabwean immigrants before they read the story. Readers oftentimes only read headlines and do not bother about the rest of the story.

Moreover, it can be said that the newspapers foregrounding content rather than authorship and mediation has to do with the dictum of objective reporting. However, it needs to be noted that the readers' interpretations of the content are filtered through the lens of their subjectivities as defined by the communicative contexts. In the situation in which jobs are scarce, poverty and crime are rife and social welfare and healthcare are wanting, uncritical recycling of discourses of exclusion will in all likelihood miseducate rather than inform the masses about the perils of such discourses. In fact, we want to argue that since concealing authorship puts the reader and content (and the quoted person(s)) in direct contact, this gives uninterrupted voice and unchallenged power to those wanting to spread anti-immigrant vitriol and hate speech. Therefore, although some readers will appreciate the 'objectivities' of the newspapers, for others anxious about job prospects, crime and other socio-economic conditions, the seamless content saves to strengthen their resolve and subjectivities against immigrants. This is because through direct speech, hate speech aimed at Zimbabwean immigrants is disseminated without evaluation. Those wanting to challenge the veracity of the message in the content cannot 
do so; at least not 'directly' and immediately. In essence, the rhetorical argument structures are more likely to reinforce hostilities against immigrants and other minority groups than curtail them. The news reporters could easily achieve a more balanced debate through careful choices of content, inclusion of immigrant voices in the news and generally being reflective about both what they write and the ideological choices that underpin the discourse structures of the content. Therefore, insights gained from this article indicate that the media needs to be critical in their reporting, especially on the emotive issue of migration.

\section{Funding}

This research received no specific grant from any funding agency in the public, commercial or not-for-profit sectors.

\section{Author biographies}

Felix Banda is a professor in the Linguistics Department, University of the Western Cape, where he teaches undergraduate and postgraduate courses in critical discourse analysis, the sociolinguistics of multilingual society and education, and technology-mediated business communication. His research interests include media and migration studies, linguistic landscapes and the semiotics of corporate identity branding and advertising.

Dr Aquilina Mawadza is a lecturer in the Linguistics Department, University of the Western Cape. Her research interests include critical discourse analysis, multimodality, media and migration studies, language and communication studies, multilingualism and African linguistics. 
1. Most immigrants to SA from Zimbabwe, http://www.news24.com/SouthAfrica/News/Mostimmigrants-to-SA-fromZimbabwe-20140715 (accessed 25 August 2014).

\section{References}

Bolter J and Grusin R (1999) Remediation: Understanding New Media. Cambridge, MA: MIT Press.

Cohen S (2002) Folk Devils and Moral Panics: The Creation of the Mods and Rockers. London: Routledge.

Crush J (2011) Complex movements, confused responses: Labour migration in South Africa.

Southern African Migration Policy Brief No. 25. Available at http://www.queensu.ca/samp/sampresources/samppublications/policybriefs/brie f25.pdf (accessed 9 September 2014).

Crush J and Tawodzera G (2014) Medical xenophobia, and the Zimbabwean migrant access to health services in South Africa. Journal of Ethnic and Migration Studies 40(4): 655-670.

Crush J and Williams V (2004) Criminal tendencies: Immigrants and illegality in South Africa.

Migration Policy $\quad$ Brief No. 10 Available at http://www.queensu.ca/samp/sampresources/samppublications/policybriefs/brie f10.pdf (accessed 10 September 2014).

Danso R and McDonald D (2001) Writing xenophobia: Immigration and the print media in post-apartheid South Africa. Africa Today 48(3): 114-137.

Davies B and Harré R (1990) Positioning: The discursive production of selves. Journal for the Theory of Social Behaviour 20(1): 44-63.

Del-Teso-Craviotto M (2009) Racism and xenophobia in immigrants' discourse: The case of Argentines in Spain. Discourse \& Society 20(5): 571-592.

Dingeman MK and Rumbaut GR (2010) The immigrant-crime nexus and postdeportation experiences: En/countering stereotypes in Southern California and El Salvador. La Verne Law Review 31(2): 363-402.

Goode E and Ben-Yehuda N (1994) Moral Panics: The Social Construction. Oxford: Blackwell.

Husbands CT (1994) Crises of national identity as moral panics: Political agenda setting about definitions of nationhood. New Community 20(2): 191-206.

Igartua JJ and Cheng L (2009) Moderating effect of group cue while processing news on immigration: Is the framing effect a heuristic process? Journal of Communication 59: 726-749. doi: 10.1111/j.1460-2466.2009.01454.x

Landau L (2008) Drowning in Numbers. Migration from Zimbabwe: Numbers, Needs and Policy Options. Johannesburg: CDE.

Li PS (2001) The racial subtext in Canada's immigration discourse. Journal of International Migration and Integration 2(1): 77-97.

Makoni SB (2012) A critique of language, languaging and supervernacular. Muitas Vozes, Ponta Grossa 1(2): 189-199. 
Murray MJ (2003) Alien strangers in our midst. Canadian Journal of African Studies 37(2/3): 440-466.

Oddo J (2012) Precontextualization and the rhetoric of futurity: Foretelling Colin Powell's UN address on NBC News. Discourse \& Communication 7(1): 25-53.

Peberdy S and Rogerson C (2000) Non-South African entrepreneurs and transnationalism in South Africa. Canadian Journal of African Studies 34(1): 2040.

Van Dijk TA (1984) Prejudice in Discourse. Amsterdam: John Benjamins.

Van Dijk TA (1989) Structures of discourse and structures of power. In: Anderson JA (ed.) Communication Yearbook 12. Newbury Park, CA: SAGE, pp. 18-59.

Van Dijk TA (1991) Racism and the Press. Routledge: London and New York.

Van Dijk TA (2001) Critical discourse analysis. In: Schiffrin D, Tannen D and Hamilton H (eds) The Handbook of Discourse Analysis. Oxford: Blackwell, pp. 352-371.

Van Dijk TA (2006) Racism and the European press. Presentation for the European Commission against racism and intolerance (ECRI). Strasbourg, 16 December 2006.

Available

at:

http://www.discourses.org/Racism\%20and\%20the\%20European\%2opress.html (accessed 9 September 2014).

Van Dijk TA (2008) Discourse and Context: A Sociocognitive Approach. New York: Cambridge University Press.

Welch M, Price E and Yankey N (2002) Moral panic over youth violence: Wilding and the manufacture of menace in the media. Youth and Society 34(1): 3-30.

Wodak R (2000a) Discourses of exclusion: A European comparative study. Speech at the Opening of the EU Observatorium, Vienna, 7/8 April, 2000.

Wodak R (200ob) Discourse and Discrimination: Rhetorics of Racism and Antisemitism. London: Routledge.

Zinyama LM and Tevera D (2002) Zimbabwe: In search of spatial and social equity. In: Lemon A and Rogerson CM (eds) Geography and Economy in South Africa and its Neighbours. London: Ashgate, pp. 231-251. 